\title{
Lapidary production in the eastern Caribbean: a typo-technological and microwear study of ornaments from the site of Pearls, Grenada
}

\author{
Catarina Guzzo Falci ${ }^{1}$ (D) Alice C. S. Knaf ${ }^{2}$ (D) - Annelou van Gijn $^{1}$ (D) $\cdot$ Gareth R. Davies $^{2}$ (D) $\cdot$ Corinne L. Hofman $^{1}$ (D)
}

Received: 2 July 2019 / Accepted: 16 October 2019 / Published online: 27 January 2020

(C) The Author(s) 2020

\begin{abstract}
The present paper examines bodily ornaments made of semiprecious lithic materials from the site of Pearls on the island of Grenada. The site was an important node in long-distance interaction networks at play between circum-Caribbean communities during the first centuries of the Common Era. Pearls was an amethyst bead-making workshop and a gateway to South America, from where certain lapidary raw materials likely originated. The importance of the site for regional archaeology and local stakeholders cannot be overstated. However, it has undergone severe destruction and looting over the decades. Here, we present a study of a private collection of ornaments from Pearls, which combines raw material identification, typo-technological analysis and microwear analysis. We identify great diversity in lithologies and in techniques adapted to their working properties. Multiple abrasive techniques for sawing, grinding, polishing and carving are identified. Furthermore, the use of ornaments is examined for the first time. Finally, we contrast our dataset to other Antillean sites and propose management patterns for each raw material. Our approach ultimately provides new insights on ornament making at Pearls and on its role in regional networks.
\end{abstract}

Keywords Ornaments $\cdot$ Technological analysis $\cdot$ Microwear analysis $\cdot$ Jade $\cdot$ Caribbean archaeology $\cdot$ Exchange

\section{Introduction}

Bodily ornaments have been regarded as proxies for the existence of large-scale exchange networks connecting the eastern Caribbean islands with northern South America, the IsthmoColombian region and Mesoamerica (Fig. 1a) (Cody 1993; Hofman et al. 2007, 2014a; Rodríguez López 1993; Rodríguez Ramos 2010; Watters 1997). In the first centuries of the Common Era, lithic materials used as ornaments were extremely varied and unequally distributed across the circumCaribbean (Chanlatte Baik 1983; Hofman et al. 2007; Murphy et al. 2000; Watters and Scaglion 1994). The identification of

Electronic supplementary material The online version of this article (https://doi.org/10.1007/s12520-019-01001-4) contains supplementary material, which is available to authorized users.

Catarina Guzzo Falci

c.guzzo.falci@arch.leidenuniv.nl

1 Faculty of Archaeology, Leiden University, Einsteinweg 2, 2333 CC Leiden, The Netherlands

2 Geology and Geochemistry Research Cluster, Vrije Universiteit Amsterdam, De Boelelaan 1085, 1081HV Amsterdam, The Netherlands workshop sites specialized in certain raw materials has further supported the idea of continuous reciprocal exchanges between islands (Hofman et al. 2007, 2014a; Watters 1997). Lapidary items have been linked to ceremonial and competitive interactions between village big men and aspiring individuals (Boomert 2001; Curet 2003; Hofman et al. 2007, 2019; Roe 1989; Siegel 2010). Despite the great interest sparked by lapidary circulation, the near absence of technological studies has hindered our understanding of the skilled production of ornaments in hard lithics. Decoding such patterns is a crucial step in acknowledging the sophistication of the indigenous heritage of the region.

The Pearls archaeological site, on the southeastern Caribbean island of Grenada $\left(-61^{\circ} 36^{\prime} 51.78^{\prime \prime} \mathrm{W} 12^{\circ} 8^{\prime}\right.$ $39.45^{\prime \prime} \mathrm{N}^{1}$; Fig. 1b), was a key node in the exchange networks connecting the Antilles with northern South America (Cody 1993; Boomert 2007; Hofman et al. 2007; Laffoon et al. 2014). The site was the locus of a lapidary workshop, with marked focus on amethyst bead making. However, the data produced since its discovery in the 1960s remains limited. This is due to the continuous

\footnotetext{
${ }^{1}$ DMS coordinates for the airport landing strip that crosses the site of Pearls. See Supplementary data 2.
} 


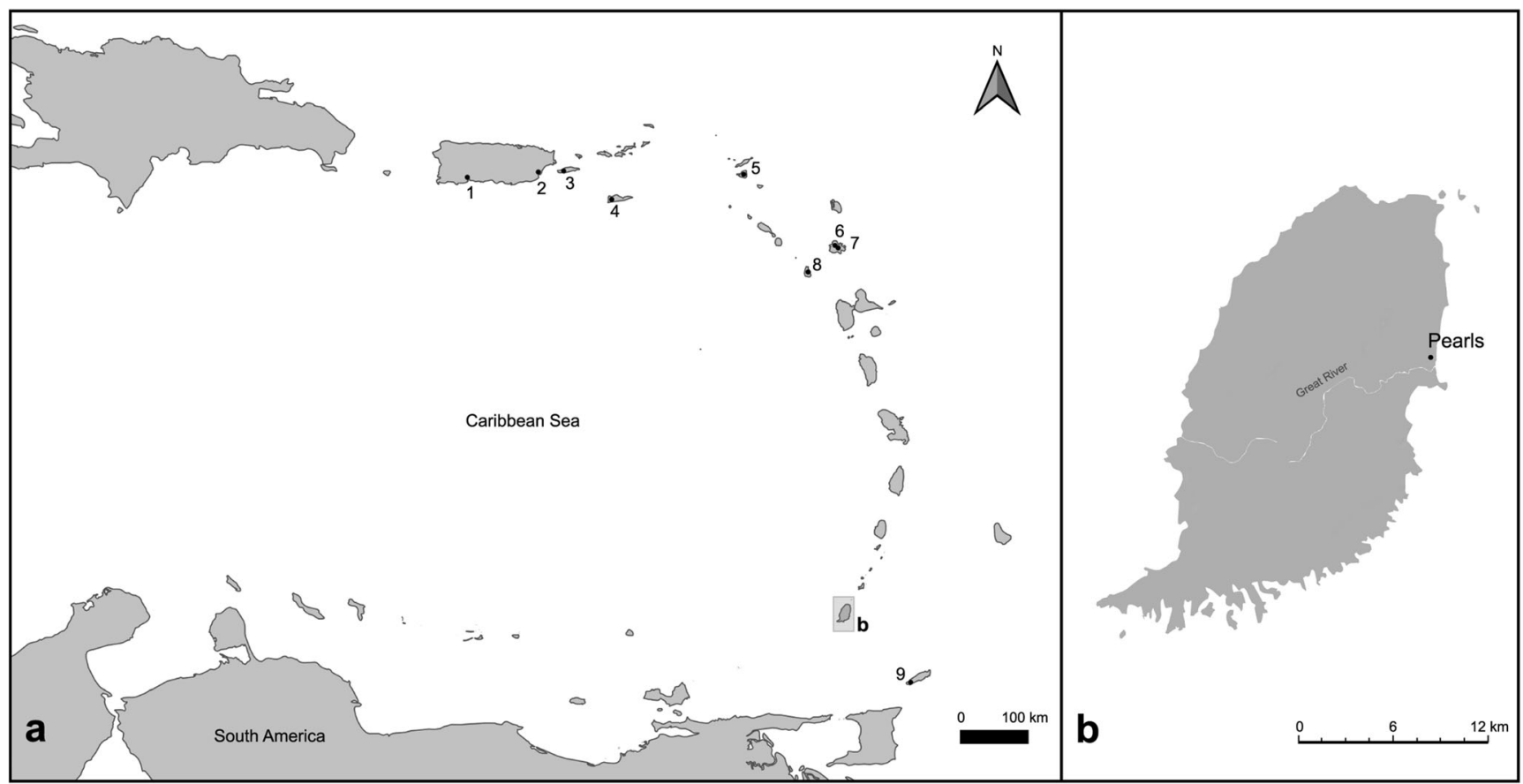

Fig. 1 a Map of the eastern Caribbean with locations of lapidary workshop sites mentioned in the text: 1 Tecla (Puerto Rico), 2 Punta Candelero (Puerto Rico), 3 La Hueca/Sorcé (Vieques), 4 Prosperity (St.

destruction, and looting the site has undergone over the decades. As this is the only lapidary workshop on the southern Antilles during this period, an investigation of its assemblages fills a significant gap in our understanding of indigenous networks. The present research is carried out in the context of a MoU between Leiden University and the government of Grenada. Our goal is to provide a thorough study of a large assemblage from Pearls, which has been unsystematically collected from the site and now makes part of a private collection. ${ }^{2}$ We assess variability in raw materials, ornament types and production technologies. Lithologies were determined by macroscopic examination with a hand lens. Production technologies and technical stages were studied through a typotechnological approach; furthermore, a microwear study of a selected sample set was carried out in order to provide an in-depth assessment of production micro-traces and use-wear.

This new data is compared with the assemblages recovered during the excavations of the Pearls site (Cody 1990; Keegan and Cody 1990) and of other eastern Caribbean sites dated to the same period (e.g. Chanlatte Baik 1983; Murphy et al. 2000; Watters and Scaglion 1994). This study provides an approach for investigating previously looted sites that hold an important place in both

\footnotetext{
${ }^{2}$ Artefacts from the collection have also been featured in previous archaeological research (Breukel 2019; Keegan and Hofman 2017, 60, 213; Petitjean Roget 2015, 147-150; Scott et al. 2018).
}

Croix), 5 Hope Estate (St. Martin), 6 Royall's (Antigua), 7 Elliot's (Antigua), 8 Trants (Montserrat), 9 Golden Grove (Tobago). b Map of Grenada with the location of the archaeological site of Pearls

archaeological narratives and society at large. At the same time, it documents this collection and makes its dataset available for a wider archaeological public. While new archaeological assessments of the site and preservation measures are necessary, we argue that the lapidary collections that have already been exposed need to be thoroughly researched. The proper documentation of such collections is indispensable to archaeological debates concerned with the specialized production and exchange of valuables across the Caribbean.

\section{Archaeological background}

The Early Ceramic Age period (400 BC-AD 600/800) has been traditionally defined by the arrival to the Antilles of pottery-bearing horticulturalist populations from northern South America (Rouse 1992, 34-37). These new occupants have been identified with the Cedrosan Saladoid and the Huecoid pottery series. More recently, the research focus has changed towards a more dynamic understanding of island occupation, involving constant voyaging, contact and exchange between communities (Curet and Hauser 2011; Hofman et al. 2007, 2014a, b, 2019; Mol 2014; Rodríguez Ramos 2010). Of particular interest, here are lapidary industries, i.e. assemblages of bodily ornaments made of a large variety of lithic materials found at several Saladoid and Huecoid sites. 


\section{State of the art on Antillean lapidary studies}

\section{Lapidary workshops}

Lapidary workshop contexts have been identified on many islands (Fig. 1a): Tecla and Punta Candelero on Puerto Rico and La Hueca/Sorcé on Vieques (Chanlatte Baik 1983; Chanlatte Baik and Narganes Storde 1989; Rodríguez López 1991), Prosperity on St. Croix (Vescelius and Robinson 1979), Elliot's and Royall's on Antigua (Murphy et al. 2000), Trants on Montserrat (Watters and Scaglion 1994), Hope Estate on St. Martin (Bonnissent 2008; Haviser 1999) and Pearls on Grenada. Their production output varied quantitatively, with some sites producing less than others (Boomert 2007). Certain sites were specialized in the working of selected raw materials (Hofman et al. 2007; Watters 1997; Watters and Scaglion 1994). However, the low chronological resolution and the use of different excavation strategies hamper true comparability between sites and inferences concerning sociopolitical organization (Curet 2003; Oliver 1999; Rodríguez Ramos et al. 2010).

\section{Raw material provenance}

Overviews of Early Ceramic Age lapidary circulation are continually revised as new data comes to light (Cody 1990, 1993; Hofman et al. 2007, 2014a; Knippenberg 2007; Rodríguez López 1993). Lithic identification has involved the use of macroscopic examination, refractive index and specific gravity tests, petrography, SEM-EDS, XRD and Raman spectroscopy (Cody 1990, 46; Cody 1993; Hardy 2008, 223-226; Murphy et al. 2000; Queffelec et al. 2018; Watters and Scaglion 1994). However, the sources of most raw materials remain uncertain. For instance, nephrite sources may be located in the Brazilian Amazon (Costa et al. 2002) or in the Sierra Nevada de Santa Marta (Acevedo Gómez et al. 2018). Turquoise veins have been reported from St. John (Virgin Islands) (Alminas et al. 1994; Knippenberg 2007, 152) and from near the mouth of the Amazon River (Costa et al. 2004). Carnelian was arguably sourced in Antigua, mainly worked in Montserrat, and exchanged with other islands (Crock and Bartone 1998; Hofman et al. 2014a; Mol 2014; Murphy et al. 2000; Watters and Scaglion 1994). Amethyst sources have been identified in Martinique and southeastern Amazonia (Cody 1993; Epstein 1988; Watters 1997). However, it is not clear whether the Antillean amethyst and turquoise sources were exploited, due to the small size of their products and the lack of evidence for local exploitation (Cody 1993; Knippenberg 2007, 168; Queffelec et al. 2018). Jadeitite sources are known in the Motagua Fault Zone on Guatemala (Foshag and Leslie 1955; Harlow et al. 2011), eastern Cuba (García-Casco et al. 2009), and northern Dominican Republic (Schertl et al. 2012). Whereas stone celts from Early Ceramic
Age sites have been identified as jadeitite, "greenstone" ornaments have been shown to be made of materials such as nephrite and serpentinite (García-Casco et al. 2013; Hardy 2008; Harlow et al. 2006; Rodríguez Ramos 2011). Quartz, calcite and diorite are found in multiple islands, hampering sourcing efforts (Boomert and Rogers 2007; Hofman et al. 2007).

\section{Production technologies}

Flaking technologies involved in lapidary production have only been studied for the site of Trants (Crock and Bartone 1998). Due to the abundance of carnelian production waste in Trants, greater focus was placed on quartz varieties. Drilling technologies have been the focus of experimental and SEM studies, with the preliminary suggestion of the use of drill bits made of wood (De Mille et al. 2008). Finally, the use of string sawing has been suggested for the creation of decorative grooves (Rodríguez Ramos 2010). The use of abrasive technologies is a crucial evidence for assessing high technological achievement, as they require great skill, fore-planning and appropriate toolkits (e.g. Beck and Mason 2002; d'Errico et al. 2000; Gwinnett and Gorelick 1979; Kenoyer and Vidale 1992; Pétrequin et al. 2012). But our current understanding of such techniques is exclusively based on the presence of associated tools, such as quartz and flint drill bits and grooved grinding stones (e.g. Chanlatte Baik 1983, 34-35; Crock and Bartone 1998; Rodríguez Ramos 2010).

\section{The site of Pearls, Grenada}

Grenada lies at approximately $145 \mathrm{~km}$ north from the island of Trinidad and the northern coast of Venezuela. The island has an area of $306 \mathrm{~km}^{2}$, with a mountainous topography whose highest peak reaches $840 \mathrm{~m}$ above sea level. Five volcanic centres have been identified on the centre and western coast of the island, with basic lava flows of basanitoids and alkalic basalts, as well as subalkalic basalts, andesites and dacites (Arculus 1976). Geologically reworked volcanics are predominant on the eastern coast. Plutonic rocks can be brought to the surface as small intrusions in the lava flow; likewise, they are occasionally found washing ashore (Arculus and Wills 1980).

The site of Pearls is located in an alluvial plain to the north of the Simon River, about $400 \mathrm{~m}$ inland from the Atlantic Ocean (Keegan and Cody 1990). Pearls is a large and dense archaeological site, covering approximately $500,000 \mathrm{~m}^{2}$ (Hanna 2019, 13; also Bullen 1964, 18). Saladoid ceramics found at Pearls were traditionally attributed to the first centuries AD (Bullen 1964). Excavations took place from 1988 to 1990 (Cody 1990; Keegan and Cody 1990); three radiocarbon dates were obtained from marine shells found in the central midden: $1711 \pm 74 \mathrm{BP}, 1725 \pm 54 \mathrm{BP}$ and $1914 \pm 51 \mathrm{BP}$ (Cody 1990). The dates were recently calibrated by Hanna (2019), who proposes a time span of AD 370-770. 
However, the occupation timespan remains unclear due to the stratigraphic complexity and extension of the site.

Domestic middens were identified at the eastern and western portions of the site, comprising faunal and plant remains, plain ceramics and beads (Cody 1990, 43). A large midden at the centre of the site (unit B) displayed decorated ceramics, hand-stones, a chert whetstone and ornaments (Cody 1990, 41). To the north, a thin midden layer (unit A) included lapidary making remains, a worn drill bit and another chert whetstone. This unit was interpreted as the setting of a lapidary workshop, where part-time craft specialists worked (Cody 1990). A map showing the location of the excavations was only recently made available (see Hanna 2019, 13). Furthermore, the site has been continuously impacted by bulldozing for airport construction, levelling, sand mining, soil removal, storm action, agriculture and long-term looting (Cody 1990, 40; Hanna 2019).

Pearls is regarded as the main centre for amethyst bead production, whose products were exchanged with the islands to the north (Boomert 2007; Hofman et al. 2007; Watters 1997). It is also an important heritage site due to both its indigenous and historic components. Destruction of the site through multiple mechanisms is still ongoing (Fitzpatrick 2012; Hanna and Jessamy 2017). Ceramic adornos and lapidary items illegally removed from Pearls are part of multiple private collections (Boomert 2007; Hofman and Hoogland 2016). In this sense, new archaeological research, recontextualization of private collections and preservation measures are necessary.

\section{Materials and methods}

The present research aimed to document lapidary artefacts that form a part of a large private collection. The studied assemblage has been reported to be exclusively from Pearls. However, this assemblage is the product of an unsystematic collection strategy: the association of artefacts to each other, to ornament making contexts, or to toolkits is unclear. There may also be diachronic variability between artefacts. Another expected bias is the low presence of artefacts in the early stages of modification.

The studied collection is composed of 1273 ornaments made of lithic raw materials, encompassing beads $(n=1056$; $82.95 \%)$, pendants $(n=167 ; 13.12 \%)$ and buttons $(n=15$; $1.18 \%)$. Many unfinished ornaments were identified $(n=$ $317 ; 24.9 \%$ ), next to crystals, unmodified pebbles and debitage $(n=29 ; 2.28 \%)$. The typological classification was based on artefact morphology and position of the suspension holes (Supplementary data 3). The sizes of beads varied between 4 and $27 \mathrm{~mm}$ of diameter and between 2 and $99 \mathrm{~mm}$ of thickness. Pendants varied from 11 to $63 \mathrm{~mm}$ of length, 6 to $40 \mathrm{~mm}$ of width and 3 to $25 \mathrm{~mm}$ of thickness. A large variety of geometric pendants was identified, both with and without carvings (Supplementary data 8, d1, g1, i1, j1; Supplementary data $9, g 1, j 1)$. Most flat pendants present a triangular morphology, although there are also rectangular, oval and square specimens. Three-dimensional pendants (Supplementary data 8, f1, h1; Supplementary data 9, b1, e1, h1, i1) have more varied shapes, afforded by larger and thicker blanks and more naturalistic carving patterns. Figure-in-profile pendants (Supplementary data 9, a1) are characterized by a triangular cross section displaying two faces with matching carvings and a narrow plain face. Finally, buttons present a broadly circular morphology, alongside a plano-convex cross section and a Vshaped perforation on one face (Supplementary data 5, f1). Their sizes varied from 11 to $15 \mathrm{~mm}$ of length, 10 to 14 of width and 7 to $10 \mathrm{~mm}$ of thickness.

A chaine opératoire approach will be used here to characterize ornament making in Pearls. This approach offers an analytical tool for the identification of technical processes and for their hierarchical organization in operational sequences (Inizan et al. 1999; Sellet 1993; Soressi and Geneste 2011). The organization of the assemblage in technical stages highlights which products are present or absent, thus pointing to the states in which materials were brought into a given site (Perlès 2007). In combination with microwear analysis, insights can be gained on use, reuse or recycling of artefacts, the inter-relation between chaines opératoires of different materials and the states in which artefacts have been disposed of (a.o. Cahen et al. 1980; Van Gijn 2012).

Lithologies were determined by examination of each ornament with a hand lens, with reference to geological collections housed at the Vrije Universiteit Amsterdam. The resulting raw material groups served as basis for the subsequent two stages of analysis. In the first stage, a typo-technological analysis of the entire lapidary assemblage was carried out. Macroscopic examination was used to identify flake scars, pecking marks, drilling traces, surface treatments, breakages, recycling, and possible use evidence. Technical stages (Table 1) were thus defined following previous studies on ornament making (Falci and Rodet 2016; Kenoyer et al. 1991; Roux 2000; Wright et al. 2008). The goal of this stage of analysis was to establish operational sequences per raw material and to assess which

Table 1 Definition of ornament-making technical stages

Technical stage Definition

Raw material Unmodified pieces (pebbles, nodules, crystals)

Debitage Flaking products (cores, flakes and blanks)

Rough-out Only knapped or sawn pieces (no grinding)

Preform $1 \quad$ Partially or completely ground preform (no perforation)

Preform 2 Preform completely ground and carved (no perforation)

Preform 3 Pieces with unfinished perforations

Complete Finished ornament (completed perforation) 
technical procedures were carried out at the site. In the second stage of the study, a sample of 100 artefacts was subjected to microwear analysis in order to identify pecking marks, abrasive techniques and use-wear (Supplementary data 1). This sample set was formed by selecting preforms and finished ornaments representing every stage present in the Pearls collection for each raw material group.

The analysis was carried out in Grenada with equipment from the Laboratory for Artefact Studies of Leiden University. A DinoLite USB digital microscope (model AD7013MZT Premier) was used for low magnification observation $(\times 20-\times$ 60). An incident light, metallographic microscope (Nikon Optiphot-1) was used for high magnification analysis $(\times 100-\times 200)$. Micrographs were made through the oculars using a digital camera (Olympus VR-340). High magnifications afford better insights into the contact materials used for treating the surface of lithic artefacts during manufacture, such as stone platforms, polishing materials and abrasives (Breukel 2019; d'Errico et al. 2000; Groman-Yaroslavski and Bar-Yosef Mayer 2015; Melgar Tísoc et al. 2013; Procopiou et al. 2013). Interpretation was based on comparison with the preliminary results of an on-going experimental programme focused on pre-colonial Caribbean technical systems (Breukel 2019; Breukel and Falci 2017; Falci 2015; Falci et al. 2017).

\section{Results: raw materials}

Lithic ornaments were split in 15 raw material categories (Supplementary data 3) (Fig. 2). Plutonic rocks are predominant in the collection, particularly diorite (29.07\% of 1273$)$. Diorite has a similar proportion of mafic to felsic minerals, resulting in a distinctive mottled white and black appearance (Supplementary data 7, a-g2). It is a hard, heterogeneous and medium to coarse-grained rock (Rapp 2009, 51). The group other than plutonic rocks encompasses great diversity (Supplementary data 7, h1-12): from specimens presenting exclusively pyroxene to specimens with nearly $100 \%$ plagioclase.

Quartz varieties are also numerous in the collection. Amethyst is a macrocrystalline quartz with purple colouration caused by the presence of iron impurities $(9.5 \%$; Supplementary data 5, a-h2). Ornaments made of both rock crystal (i.e. translucent and colourless specimens) and milky quartz were grouped together as "quartz" (9.8\%; Supplementary data 5, i1-m3). Macrocrystalline quartz varieties are characterized by their composition $\left(\mathrm{SiO}_{2}\right)$, conchoidal fracture and hardness of 7 in Mohs scale (Oldershaw 2009, 184-185). Carnelian is a microcrystalline quartz variety, with hardness of 6.5 , conchoidal fracture and yellow to red colour (5.2\%; Supplementary data 6, a-g2). Turquoise was one of the most numerous raw materials $(13.3 \%$; Supplementary data 6 , $\mathrm{h} 1-\mathrm{k} 2$ ). It is a hydrated phosphate of copper and aluminium, being opaque and displaying a light to intense blue colour. It is a brittle mineral, also having a conchoidal fracture and hardness of 5-6 in Mohs scale.

Among metamorphic rocks, the most numerous is jadeitite $\left(\mathrm{Na}\left(\mathrm{Al}_{2} \mathrm{Fe}^{3+}\right) \mathrm{Si}_{2} \mathrm{O}_{6}\right)(13 \%)$. Jadeite is a high pressure pyroxene mineral, which is very tough and hard (6.5-7 in Mohs scale) and has a splintery to uneven fracture. In the studied collection, jadeitite appears as a light green opaque rock and as a coarse-grained and sparkly granular rock (Supplementary data 8, a-i4). Other metamorphosed ultramafic rocks with serpentine alteration were also identified $(0.8 \%$; Supplementary data 9, g1-j2). Nephrite $\left(\mathrm{Ca}_{2}\left(\mathrm{Mg}, \mathrm{Fe}^{2+}\right)_{5} \mathrm{Si}_{8} \mathrm{O}_{22}(\mathrm{OH})_{2}\right)$ is a tremolite-actinolite rock, characterized by its considerable toughness and hardness (6.5 in Mohs scale), being also fibrous and elastic (2\%, Supplementary data 9, a1-e4). Other metamorphic rocks rich in tremolite were also identified $(2.12 \%)$. Specimens were often opaque and with pronounced schistosity (Supplementary data 9, f1-h4). Low temperature hydrothermal alteration products $(2.12 \%)$ also presented different shades of green (Supplementary data 8, j1-k2).

\section{Results: production sequences}

In general, the studied collection is well preserved. Fragmentation is present in 23 artefacts among the 100 analysed specimens, but only three of them are recent breaks. Traces produced by contact with heat are not common in the general assemblage, but almost ubiquitous among carnelian artefacts. This may be an indication that carnelian was heattreated for better workmanship and colour, as known from other regions of the world (Kenoyer et al. 1991; Roux 2000).

The most common raw materials were predominantly used for the production of beads, for instance, macro- and microcrystalline quartz varieties $(n=275)$, diorite $(n=369)$ and a yellowish variety of plutonic rocks containing few mafic minerals $(n=62)$ (Supplementary data 7, k1-12). Many beads were also made of jadeitite $(n=106)$ and turquoise $(n=157)$. The main raw materials used for the production of pendants were jadeitite $(n=57)$, nephrite $(n=18)$, diverse metamorphic rocks $(n=41)$ and other plutonic rocks $(n=64)$. Buttons were only made of quartz, amethyst and opal. The debitage is predominantly made of quartz varieties and diverse metamorphic rocks (Supplementary data 4). Table 2 compiles all identified production techniques for each raw material group (see also Supplementary Data 1).

\section{Blank production}

\section{Flaking}

Debitage products are present in low numbers in the assemblage, thus limiting our understanding of the early stages of raw material exploitation. Most ornament preforms and 
a

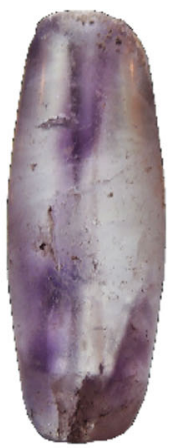

b

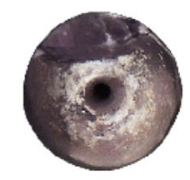

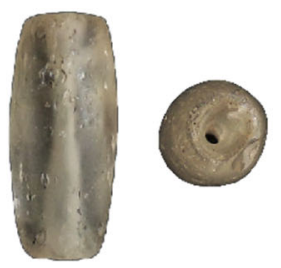

c

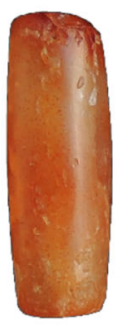

d

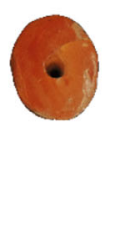

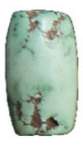

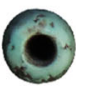

e

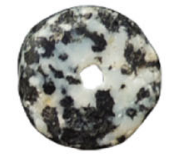

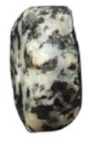

f
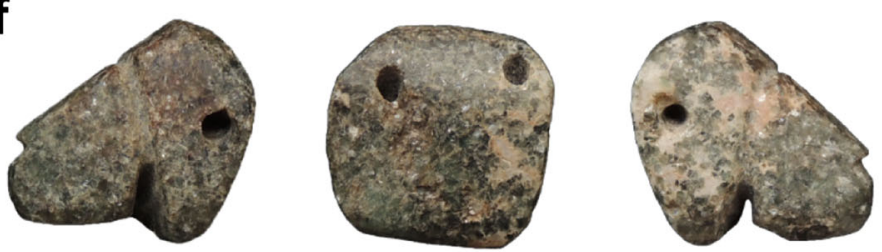

g

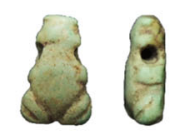

h
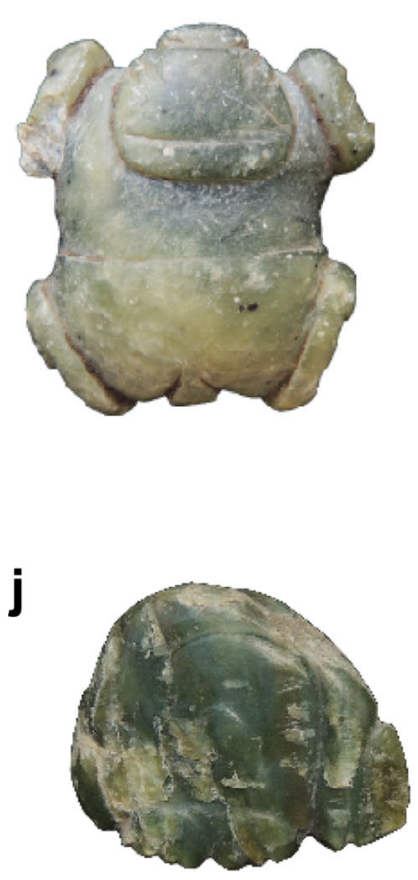
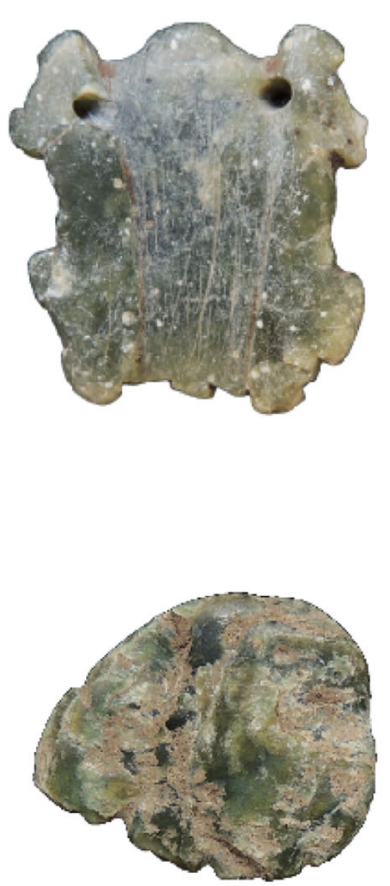

i
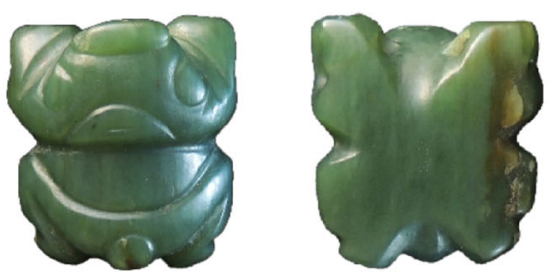

$\mathbf{k}$
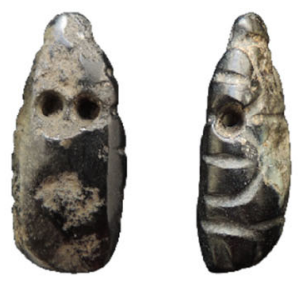

$3 \mathrm{~cm}$
Fig. 2 Main raw material groups found in the studied collection: a amethyst, b quartz, c carnelian, $\mathbf{d}$ turquoise, e diorite, $\mathbf{f}$ other plutonic

rough-outs do not retain remnants of natural surfaces. Exceptions are the preforms of a quartz button and of an amethyst tubular bead, which display crystal facets. The scars on flaked amethyst cores point to the production of small flakes (with a maximum of $1 \mathrm{~cm}$ length), possibly to be used as rocks, $\mathbf{g}$ low temperature alteration products, $\mathbf{h}$ jadeitite, $\mathbf{i}$ nephrite, $\mathbf{j}$ metamorphic with tremolite, and $\mathbf{k}$ metamorphosed ultramafics".

blanks for disc beads. Flake scars were observed on a core point to the use of percussion on an anvil to work it from multiple directions (Supplementary data 5, a). Small carnelian pebbles are also present, alongside a partially flaked core (Supplementary data 6, a). A jadeitite core displays flake 
Table 2 Production techniques identified for each technical operation and raw material ${ }^{\mathrm{a}}$

\begin{tabular}{|c|c|c|c|c|c|c|c|}
\hline & Blank acquisition & Shaping & Surface treatment & Decorating & Drilling & Technical errors/recycling & Total \\
\hline Amethyst & Flaking & $\begin{array}{l}\text { Flaking } \\
\text { Pecking }\end{array}$ & $\begin{array}{l}\text { Grinding } 1,2 \\
\text { Polishing } 1\end{array}$ & - & Biconical & $\begin{array}{l}\text { Re-pecking } \\
\text { Re-grinding } \\
\text { Second hole }\end{array}$ & 121 \\
\hline Quartz & Flaking & $\begin{array}{l}\text { Flaking } \\
\text { Pecking }\end{array}$ & $\begin{array}{l}\text { Grinding 1, } 2 \\
\text { Polishing } 1,2,3\end{array}$ & - & Biconical & Poorly aligned perforations & 125 \\
\hline Carnelian & Flaking & $\begin{array}{l}\text { Flaking } \\
\text { Pecking }\end{array}$ & $\begin{array}{l}\text { Grinding 1,2 } \\
\text { Polishing 1, 2, } 3\end{array}$ & - & $\begin{array}{l}\text { Biconical } \\
\text { Conical }\end{array}$ & - & 66 \\
\hline Calcite & No evidence & $\begin{array}{l}\text { Flaking (?) } \\
\text { Notching }\end{array}$ & $\begin{array}{l}\text { Grinding } 1 \\
\text { Polishing } 3\end{array}$ & Incising & $\begin{array}{l}\text { Biconical } \\
\text { Bi-cylindrical }\end{array}$ & - & 6 \\
\hline Turquoise & $\begin{array}{l}\text { Sawing } \\
\quad \text { (rigid saw?) }\end{array}$ & $\begin{array}{l}\text { Flaking } \\
\text { Notching }\end{array}$ & $\begin{array}{l}\text { Grinding 1, } 2 \\
\text { Polishing } 3\end{array}$ & $\begin{array}{l}\text { Incising } \\
\text { Notching }\end{array}$ & $\begin{array}{l}\text { Biconical } \\
\text { Bi-cylindrical }\end{array}$ & Poorly aligned perforations & 169 \\
\hline Diorite & $\begin{array}{l}\text { Sawing (rigid saw) } \\
\text { Flaking }\end{array}$ & $\begin{array}{l}\text { Flaking } \\
\text { Notching }\end{array}$ & $\begin{array}{l}\text { Grinding 1, } 2 \\
\text { Polishing 1, } 3\end{array}$ & Notching & $\begin{array}{l}\text { Biconical } \\
\text { Conical } \\
\text { Cylindrical }\end{array}$ & $\begin{array}{l}\text { Re-grinding } \\
\text { Second hole }\end{array}$ & 370 \\
\hline Other plutonics & $\begin{array}{l}\text { Sawing (rigid saw) } \\
\text { Sawing (string) }\end{array}$ & Notching & $\begin{array}{l}\text { Grinding 1, } 2 \\
\text { Polishing 2,3 }\end{array}$ & $\begin{array}{l}\text { Incising } \\
\text { Excising }\end{array}$ & $\begin{array}{l}\text { Biconical } \\
\text { Bi-cylindrical }\end{array}$ & $\begin{array}{l}\text { Second hole } \\
\text { Re-grinding } \\
\text { Poorly aligned perforations }\end{array}$ & 99 \\
\hline Jadeitite & $\begin{array}{l}\text { Flaking } \\
\text { Sawing (rigid saw) }\end{array}$ & $\begin{array}{l}\text { Flaking } \\
\text { Notching }\end{array}$ & $\begin{array}{l}\text { Grinding 1, } 2 \\
\text { Polishing 2, } 3\end{array}$ & $\begin{array}{l}\text { Notching } \\
\text { Incising } \\
\text { Excising } \\
\text { Drilling }\end{array}$ & Biconical & Re-grinding & 166 \\
\hline Nephrite & $\begin{array}{l}\text { Sawing (rigid saw?) } \\
\text { Sawing (string) }\end{array}$ & $\begin{array}{l}\text { Notching } \\
\text { Pecking } \\
\text { Flaking }\end{array}$ & $\begin{array}{l}\text { Grinding 1, } 2 \\
\text { Polishing 1, } 3\end{array}$ & $\begin{array}{l}\text { Incising } \\
\text { Notching } \\
\text { Drilling }\end{array}$ & $\begin{array}{l}\text { Biconical } \\
\text { Cylindrical }\end{array}$ & - & 26 \\
\hline $\begin{array}{l}\text { Metamorphosed } \\
\text { ultramafics }\end{array}$ & Sawing (?) & $\begin{array}{l}\text { Flaking } \\
\text { Notching }\end{array}$ & $\begin{array}{l}\text { Grinding 1, } 2 \\
\text { Polishing } 3\end{array}$ & Incising & Biconical & - & 11 \\
\hline $\begin{array}{l}\text { Metamorphic with } \\
\text { tremolite }\end{array}$ & Sawing (rigid saw) & $\begin{array}{l}\text { Notching } \\
\text { Drilling }\end{array}$ & Polishing 3 & Incising & Biconical & Re-polishing and carving & 27 \\
\hline $\begin{array}{l}\text { Low temperature } \\
\text { alteration product }\end{array}$ & $\begin{array}{l}\text { Flaking } \\
\text { Sawing (?) }\end{array}$ & $\begin{array}{l}\text { Flaking } \\
\text { Notching }\end{array}$ & Grinding 1,2 & Incising & Biconical & $\begin{array}{c}\text { Poorly aligned } \\
\text { perforations }\end{array}$ & 27 \\
\hline
\end{tabular}

${ }^{\text {a }}$ Opal $(n=1)$, basement schist $(n=2)$ and indeterminate $(n=57)$ are not included in this table

removals made from multiple directions through hard hammer percussion (Supplementary data 8, a). A flaked diorite core has been observed on the surface of the site by one of the authors. These cores point to the use of flaking in the early stages of ornament making. The lack of flaking evidence in other raw materials may be connected to the poor suitability of this technique for working tough and/or heterogeneous materials.

\section{Sawing}

Sawing was used for blank production through a groove-andsnap technique. Small beads of diorite and turquoise were made by splitting a long blank in small sections (Supplementary data 7, a, e1). The blanks for geometric, three-dimensional and figure-in-profile pendants were also produced in this way. Such multi-ornament preforms were ground prior to sawing, so that sawing products already had the desired shape to be made into ornaments. A second grinding operation removed sawing traces and irregularities left from snapping. We identified two types of traces produced by sawing: (1) cut grooves with triangular cross section, in which the bottom is markedly narrower than the outer edges and the sides display straight scratches and (2) narrow cut grooves (ca. $2 \mathrm{~mm}$ ) with parallel sides and a convex bottom, on which semi-circular scratches are visible. The first set of traces has been attributed to the use of rigid straight saws possibly made of lithic materials (Supplementary data 8, c1, c2; Supplementary data 9, f1). The second set of traces was attributed to sawing with a string accompanied by abrasives (Kovacevich 2011; Sax and Ji 2013). Such traces correspond to those obtained in previous experiments sawing conch shell, diorite and amber with cotton strings (Breukel and Falci 2017; Falci 2015, 146-148; Verchoof and Van der Vaart 2010). String sawing was attested on (multi-)pendant preforms (Supplementary data 7, h1-h3, i1-i3; Supplementary data 9, a2, b2). Preliminary cut grooves made with rigid saws were placed to fix the string for sawing. String sawing was then carried out in both parallel and perpendicular plans on plutonic rock preforms, suggesting that it was adapted to the shape of the block to be sawn.

\section{Shaping}

Flaking was used to shape the sides and sometimes the faces of beads made of quartz varieties. Pressure flaking has been 
identified on beads from Trants, being used for the controlled removal of small flakes (Crock and Bartone 1998, 213). In the Pearls collection, the flake scars observed on rough-outs and preforms are small, narrow and long, giving the beads an irregular faceted appearance (Supplementary data 5, b1; Supplementary data 6, b1). The flake scars are often superposed by pecking and grinding traces, thus preventing further technological characterization. Similarly, faceted sides were sometimes observed on turquoise, diorite and nephrite beads (Supplementary data 6, i1; Supplementary data 7, b1).

Pecking traces can be recognized as several adjacent concentric impact craters (Supplementary data 5, b1, b2, c1). The use of microscopy permitted their identification even when the traces had been largely removed by subsequent surface treatments (Supplementary data 5, b3, c1, c2, f2, i2; Supplementary data 6, b2, c2). Pecking was used as a means of removing excessive material, sharp ridges left by flaking and grinding facets (Supplementary data 5, h2, k2, k3).

\section{Surface treatments}

Different grinding and polishing types were identified on the samples studied through microwear analysis. The characteristics of the observed polishes are produced by differences in the nature of the tool, abrasives and coolants used. They are further dependent on the raw materials of the ornaments themselves, as their mechanical properties vary greatly. Half of the ornaments display partially overlapping polishes that result from the successive application of different surface treatments.

\section{Grinding}

A first rough grinding stage (grinding 1) was noted across different materials $(n=34)$. In this stage, the shape of the ornament is defined, but in many cases, the surface remains dull and faceted. Pecking traces are gradually replaced by abraded patches on the tops of the microtopography, sometimes with incipient striations (Supplementary data 5, b3, d2; Supplementary data 6, b2, c2, h2; Supplementary data 7, b2, c2; Supplementary data 8, d2, j2). The general flattening of the micro-surface and the overall absence of polish suggests the use of a hard contact material without water. Grinding 2 is characterized by the presence of a continuous polish located on the tops of the microtopography $(n=53)$. Furthermore, it displays fine and regularly spaced striations on a flat and bright polish (Supplementary data 5, e3, j2, j3; Supplementary data 6, i2, i3; Supplementary data 8, e2; Supplementary data $9, \mathrm{~h} 3$ ). This treatment is likely the result of the use of a grinding stone with added abrasives and water.

\section{Polishing}

Polishing is directed toward erasing manufacturing traces, smoothening the surface and increasing the sheen of the material. Different polishing types can be distinguished. Polishing 1 is characterized by a flat mirror-like polish ( $n=$ 14). Hard fine-grained stone platforms with added water could have produced this type of polishing, such as the chert whetstones found at Pearls (Cody 1990, 41-42). Polishing 1 is commonly seen on certain sectors of plano-convex and tubular beads, as well as on buttons (Supplementary data 5, e3, f2, k3; Supplementary data 6, g2; Supplementary data 7, d2, d3, j2; Supplementary data 9, d2, d3). The polished shiny surfaces would be visible when the buttons are attached to a composition, whereas the surfaces with dull surface treatment are hidden. Polishing 2 is characterized by domed and smooth patches of polish $(n=5)$. It is not continuous or extensively developed, leaving the general microtopography rough and irregular (Supplementary data 5, i2). Polishing 3 is greasy, bright and invasive, reaching the lowest interstices of the microtopography $(n=45)$. It often displays abundant fine scratches, created by the use of abrasives. The polish was produced with unidentified soft and pliable contact materials (Supplementary data 6, e2, j2; Supplementary data 7, e2, f2, j3; Supplementary data 8, f2, k2; Supplementary data 9, a3, h4).

\section{Carving}

Shaping and decorating operations carried out through sawing can be divided into notching, incising and excising. Notching refers to the creation of indentations on the sides of ornaments in order to give them elaborate shapes, often zoomorphic ( $n=$ $28)$. Incising was used to create decorative lines and zoomorphic depictions $(n=19)$. Excision involved the combined use of incising and notching to isolate certain sectors of a pendant, thus giving to a depiction greater naturalism $(n=5)$.

The cross-section of cut grooves varies according to the specific shape and raw material of the tool used. Sharp, Vshaped notches were observed on nine specimens $(29 \%$ of 31 carved specimens; Supplementary data 7, k1; Supplementary data 8, f3, f4; Supplementary data 9, e2, h2). They were likely made with hard lithic tools, such as the flaked chert tools recovered from the site (Cody 1990, 4142, 57-58). Notches were sometimes made through multiple cuts, creating a wide and composite groove (Supplementary data 7, j4; Supplementary data 8, h2). The remaining artefacts displayed U-shaped grooves (67.7\%; Supplementary data 8, i2; Supplementary data 9, c2, c3). Lithic tools that are not as hard, fine-grained and brittle as chert may have been used to produce such wider notches. Alternatively, U-shaped grooves displaying linear scratches may be the result of widening and polishing after their initial carving. Widening may have been carried out using organic saws with abrasives, which have a rounded cross-section or wear more easily when working hard lapidary materials. Three frog-shaped pendants display wide and shallow central incisions with abundant and continuous 
Table 3 Distribution of ornaments analysed by microwear according to raw material and presence of use-wear in this analysed sample

\begin{tabular}{|c|c|c|c|c|c|c|c|}
\hline & \multicolumn{3}{|c|}{ Analysed sample $(n=100)$} & \multicolumn{4}{|c|}{ Complete artefacts $(n=71)$} \\
\hline & \multirow[t]{2}{*}{ Total } & \multirow[t]{2}{*}{ Unfinished } & \multirow[t]{2}{*}{ Complete } & \multicolumn{2}{|c|}{ Use-wear } & \multirow{2}{*}{$\begin{array}{l}\text { No use- } \\
\text { wear }\end{array}$} & \multirow[t]{2}{*}{ Indeterminate } \\
\hline & & & & $n$ & $\%$ & & \\
\hline Amethyst & 11 & 3 & 8 & 1 & 12.50 & 7 & - \\
\hline Quartz & 8 & 2 & 6 & 1 & 16.67 & 2 & 3 \\
\hline Carnelian & 8 & 3 & 5 & 1 & 20 & 4 & - \\
\hline Calcite & 2 & - & 2 & 1 & 50 & 1 & - \\
\hline Turquoise & 8 & 2 & 6 & 3 & 50 & 3 & - \\
\hline Diorite & 14 & 3 & 11 & 4 & 36.36 & 4 & 3 \\
\hline Other plutonics & 14 & 4 & 10 & 7 & 70 & 2 & 1 \\
\hline Jadeitite & 18 & 6 & 12 & 8 & 66.67 & 3 & 1 \\
\hline Nephrite & 7 & - & 7 & 6 & 85.71 & 1 & - \\
\hline Metamorphosed ultramafics & 3 & 2 & 1 & 1 & 100 & - & \\
\hline Metamorphics with tremolite & 2 & 2 & - & - & - & - & - \\
\hline $\begin{array}{l}\text { Low temperature alteration } \\
\text { product }\end{array}$ & 2 & - & 2 & 1 & 50 & 1 & - \\
\hline Basement schist & 1 & 1 & - & - & - & - & - \\
\hline Indeterminate & 2 & 1 & 1 & 1 & 100 & - & - \\
\hline Total & 100 & 29 & 71 & 35 & - & 28 & 8 \\
\hline
\end{tabular}

striations (Supplementary data 8, g2; Supplementary data 9, b3, i1, i2). Such incisions were likely produced by the use of pliable soft materials (e.g. plant leaf or strips of hide), which were pulled back-and-forth while the pendants were held still. Finally, drilling was used for creating decorative circular depressions on three zoomorphic pendants (Supplementary data 9, a1, c1, c2).

\section{Perforation}

Drilling was used for creating the suspension holes. Most perforations are biconical ( $83.1 \%$ of 83$)$, i.e. the holes are formed by two opposing cones, each presenting a tapering profile (Supplementary data 5, d1, g2, h2, k1, 11; Supplementary data 8, g3, h3, h4; Supplementary data 9, j2). Abundant and regular circular scratches are observed on the perforation walls. This indicates the use of solid (non-hollow) drill bits across all raw materials, in contrast to the use of hollow drills reported for the site of Trants (Crock and Bartone 1998, 213). The diameter of the perforations varied between 1.0 and $6.0 \mathrm{~mm}$ (measured on the surface), with most specimens presenting between 2.0 and $3.0 \mathrm{~mm}(68.6 \%)$. The perforations of beads made of quartz varieties are of up to $4.5 \mathrm{~cm}$ in length, whereas they are of up to $10 \mathrm{~cm}$ in the plutonic rock beads. Semi-circular striations were observed in association with a bright and flat polish adjacent to the rim of the perforation of some quartz and carnelian beads (Supplementary data 6, b3, b4, f2, f3). This polish suggests the use of a lithic drill. This is in agreement with purported chert and quartz drill bits recovered from Pearls and other lapidary workshops. However, experimental studies have questioned the suitability of chert for drilling ornaments made of materials of comparable hardness (Gurova et al. 2013). In fact, some tool variability can be attested: while most perforations are biconical, the sector where the cones meet in the centre of the bead can have a cylindrical cross-section and be quite narrow (less than $1.0 \mathrm{~mm}$; Supplementary data 5, g2). This suggests the use of a different and smaller tool for uniting the perforation cones. Likewise, cylindrical perforations with discreet tapering were noted on nine artefacts made of nonquartz materials $(10.8 \%)$. Cylindrical perforations may have been produced by drill bits made of different raw materials.

We noted unperforated ornaments displaying a highly developed polishing and fully perforated specimens with a coarse surface treatment and faceted sides. Drilling traces on some specimens are sometimes quite fresh, suggesting that these sectors were not reground or polished after drilling. In this sense, the order between polishing and drilling was not strict. This evidence suggests that some flexibility were afforded in ornament production sequences.

\section{Technical errors and recycling}

Artefacts displaying technical errors were noted in the studied collection, namely ornaments (1) with unfinished perforations (preform 3), (2) with poorly aligned perforation cones, (3) broken along the perforation and (4) that snapped in the wrong place. This collection was recovered from a site containing workshop contexts; in this sense, many of such artefacts may have been perceived as undesirable products to be 
discarded. Likewise, 12 recycled beads and pendants were observed (Table 2; Supplementary data 1). Recycling was carried out through the (re-)application of various techniques, such as grinding (Supplementary data 5, e1, e2; Supplementary data 7,11) and drilling. Recycling has also been noted in other lapidary workshops, being interpreted as an efficient management of rare raw materials (Durand and Petitjean-Roget 1991; Narganes Storde 1995, 1999; Rodríguez López 1991).

\section{Results: use-wear}

Of the 100 artefacts studied through microwear analysis, only specimens with complete perforations are considered in this section $(n=71)$. Many studied artefacts display a fresh and partially ragged rim of perforation when examined with microscopy (39.4\% of 71). In addition, the intersection of the cones in the centre of the perforation is often narrow and fragile. The lack of use-wear did suggest that such ornaments were not strung. In contrast, almost half of the studied ornaments display use-wear (49.2\%) in the form of smoothening of the rim of perforation and formation of a distinctive polish. The perforation becomes more uniform as a result of the progressive erasure of drilling traces. In double perforated pendants, use-wear often led to the deformation of the perforation rims dependant on the position of the string (Supplementary data 8, g3, g4, i3, i4, j3; Supplementary data 9, e3, e4). Another observed use-wear type was the formation of polish and rounding on the edges of the pendants due to the contact with the body during use. Table 3 presents the percentage of artefacts with use-wear per analysed raw material group. General trends can be noted despite the reduced sample size. Nearly all nephrite ornaments present use-wear (85.7\%). Jadeitite, plutonic rocks and turquoise also present notable percentages of used artefacts (Supplementary data 6, k2; Supplementary data 7, f3, g2, k1, k2, 11, 12). In contrast, a relatively low percentage of amethyst and carnelian ornaments displays use-wear (12.5\% and 20\%). Quartz also records a low percentage of used specimens (16.6\%; Supplementary data $5, \mathrm{~m} 2, \mathrm{~m} 3$ ), although the evidence was not conclusive on three other beads. This is a low value when contrasted to the large numbers of analysed ornaments for each of these quartz varieties.

\section{Discussion}

The present study documented unprecedented variability in the collection from the site of Pearls. In an effort to recontextualize it, we now compare the typological and raw material variability observed with assemblages from other eastern Caribbean sites.

\section{Ornament typology}

Considerable archaeological debate has taken place regarding the chronological and socio-cultural relations between the Saladoid and Huecoid series, with focus on site distributions and relative chronologies based on ceramic styles (Chanlatte Baik 1983; Chanlatte Baik and Narganes Storde 1989; Roe 1989; Rouse 1992; Rouse and Alegría 1990). However, no conclusive decisions have been reached after decades of debate (Oliver 1999; Rodríguez Ramos et al. 2010; also Keegan and Hofman 2017, 67-68). With regard to lapidary materials, distinctive styles have also been proposed and attributed to one of the series.

\section{Comparison with Saladoid lapidary production}

It has been argued that Saladoid lapidary production is more limited, homogeneous and stylistically different from the Huecoid varieties (Bérard 2013; Chanlatte Baik and Narganes Storde 1989; Narganes Storde 1995, 1999; Rodríguez Ramos et al. 2010). The former is characterized by tubular and barrel-shaped beads made of quartz, amethyst, carnelian and diorite (Murphy et al. 2000; Narganes Storde 1999; Watters and Scaglion 1994). The studied beads are very similar to those recovered from Saladoid sites in Montserrat and Antigua. At the same time, we identified other ornament types, such as disc beads, buttons and a pendant. The two first types had already been reported during the excavations of Pearls (Cody 1990, 54) and of Sorcé and Tecla (Narganes Storde 1999). Beads and pendants of other materials, such as turquoise, malachite, calcite and jasper, have been recovered from sites associated to both archaeological series.

Zoomorphic pendants are known from Saladoid contexts, notably three-dimensional frog-shaped pendants (e.g. Bonnissent 2008, 491; Durand and Petitjean-Roget 1991; Murphy et al. 2000; Narganes Storde 1999). There is considerable stylistic and material variability between known specimens. The two nephrite three-dimensional frog-shaped pendants from Pearls are similar to specimens often referred to as muiraquitãs, due to their similarity to Amazonian pendants (Boomert 1987; Cody 1993; Costa et al. 2002).

\section{Comparison with Huecoid lapidary production}

The sites of La Hueca and Punta Candelero contained large numbers of "segmented frog pendants". These are flatschematized frog-shaped pendants with a perforation across the neck and made of varied raw materials (serpentinite, jasper, nephrite and calcite) (Chanlatte Baik 1983, 16; Cody 1993; Narganes Storde 1995, 142). Few of such specimens are found in the studied collection $(n=6$; Supplementary data $8, \mathrm{j} 1)$, mostly made of jadeitite. The abundance and stylistic variability of small and flat frog-shaped pendants led us to 
Table 4 Raw material management at the site of Pearls based on the studied collection

\begin{tabular}{|c|c|c|c|c|}
\hline Raw materials & Suggested geological sources ${ }^{\mathrm{a}}$ & Local production & Which stages & Brought into the site \\
\hline Amethyst $(n=121)$ & $\begin{array}{l}\text { Martinique } \\
\text { Southeastern Amazon } \\
\quad \text { (Brazil) }\end{array}$ & Yes (beads and buttons) & All stages & Raw material \\
\hline Quartz $(n=125)$ & $\begin{array}{l}\text { Available throughout } \\
\text { the archipelago }\end{array}$ & $\begin{array}{l}\text { Yes (beads and buttons) } \\
\text { Minor evidence } \\
\text { (pendants) }\end{array}$ & All stages & Raw material \\
\hline Carnelian $(n=66)$ & Antigua & Yes (beads) & $\begin{array}{l}\text { Disc bead production } \\
\text { Finishing barrel-shaped } \\
\text { beads }\end{array}$ & $\begin{array}{l}\text { Raw material (pebbles) } \\
\text { Preforms of barrel-shaped } \\
\text { beads } \\
\text { Finished tubular beads }\end{array}$ \\
\hline Turquoise $(n=169)$ & $\begin{array}{l}\text { St. John (Virgin Islands) } \\
\text { Lower Amazon (Brazil) }\end{array}$ & Yes (beads and pendants) & $\begin{array}{l}\text { Polishing } \\
\text { Drilling }\end{array}$ & $\begin{array}{l}\text { Preforms } \\
\text { Finished beads } \\
\text { and pendants }\end{array}$ \\
\hline Diorite $(n=370)$ & $\begin{array}{l}\text { Tobago } \\
\text { Available throughout } \\
\text { the archipelago }\end{array}$ & Yes (beads and pendants) & $\begin{array}{l}\text { All stages } \\
\text { Flaking (minor evidence) } \\
\text { Shaping (minor } \\
\quad \text { evidence) }\end{array}$ & $\begin{array}{l}\text { Raw material } \\
\text { Preforms }\end{array}$ \\
\hline $\begin{array}{l}\text { Other plutonics } \\
\quad(n=99)\end{array}$ & $\begin{array}{l}\text { Available throughout } \\
\text { the archipelago }\end{array}$ & $\begin{array}{l}\text { Yes (pendants) } \\
\text { No evidence (beads) }\end{array}$ & All stages (pendants) & $\begin{array}{l}\text { Raw material } \\
\text { Partially worked } \\
\text { specimens to be made } \\
\text { into pendants (?) } \\
\text { Beads }\end{array}$ \\
\hline Jadeitite $(n=166)$ & $\begin{array}{l}\text { Northern Dominican } \\
\text { Republic } \\
\text { Eastern Cuba } \\
\text { Motagua Fault Zone } \\
\quad \text { (Guatemala) }\end{array}$ & $\begin{array}{l}\text { Yes (pendants) } \\
\text { Minor evidence (beads) }\end{array}$ & All stages & $\begin{array}{l}\text { Raw material } \\
\text { Bead preforms } \\
\text { Finished beads }\end{array}$ \\
\hline Nephrite $(n=26)$ & $\begin{array}{l}\text { Lower Amazon (Brazil) } \\
\text { Sierra Nevada de Santa } \\
\text { Marta (Colombia) }\end{array}$ & $\begin{array}{l}\text { Yes (beads and pendants } \\
\text { in light green variety) }\end{array}$ & $\begin{array}{l}\text { Grinding } \\
\text { Polishing } \\
\text { Drilling }\end{array}$ & $\begin{array}{l}\text { Pebbles (light green variety) } \\
\text { Preforms (light green variety) } \\
\text { Finished pendants } \\
\quad \text { (dark green variety) }\end{array}$ \\
\hline $\begin{array}{l}\text { Metamorphosed } \\
\text { ultramafics } \\
(n=11)\end{array}$ & $\begin{array}{l}\text { Greater Antilles } \\
\text { South America }\end{array}$ & Yes (mostly pendants) & $\begin{array}{l}\text { Grinding } \\
\text { Polishing } \\
\text { Drilling }\end{array}$ & $\begin{array}{l}\text { Raw material (?) } \\
\text { Blanks, rough-outs, } \\
\text { preforms (?) } \\
\text { Finished beads and pendants (?) }\end{array}$ \\
\hline $\begin{array}{l}\text { Metamorphic rocks } \\
\text { with tremolite } \\
(n=27)\end{array}$ & $\begin{array}{l}\text { Greater Antilles } \\
\text { South America }\end{array}$ & Yes (pendants) & $\begin{array}{l}\text { All stages, except for } \\
\text { blank acquisition }\end{array}$ & $\begin{array}{l}\text { Raw material } \\
\text { Blanks, rough-outs (?) }\end{array}$ \\
\hline $\begin{array}{l}\text { Low temperature } \\
\text { alteration products } \\
(n=27)\end{array}$ & $\begin{array}{l}\text { Available throughout } \\
\text { the archipelago }\end{array}$ & $\begin{array}{l}\text { Yes (pendants) } \\
\text { Minor evidence (beads) }\end{array}$ & All stages & $\begin{array}{l}\text { Raw material } \\
\text { Finished beads } \\
\text { Bead preforms }\end{array}$ \\
\hline
\end{tabular}

a Based on bibliographic references mentioned in the "Raw material provenance" section

group them under the broader subtype "carved flat pendants", as they were made on similar blanks. Pendants that do not fit in the segmented frog type were also found at La Hueca, but in comparatively low numbers (Chanlatte Baik 1983, 43; Narganes Storde 1995). Many plain geometric pendants noted in the Pearls collection share the same production sequence as the flat frog-shaped pendants, but do not display carvings. Pendants shaped as raptorial birds were also numerous in Huecoid sites. As the pendants are thought to depict bird species not endemic to the Antilles, they have been regarded as evidence of the continental origins of Huecoid people (Chanlatte Baik 1983, 40-42; Chanlatte Baik and Narganes Storde 1989). A single specimen has been reported from another private collection from Pearls (Boomert 2007). The studied figure-in-profile pendants share certain morphological features with the bird pendants: the orientation of the carved figure and the blank morphology obtained by sawing. This similarity is also noted by Narganes Storde (1995, 144), who suggests that the figure-in-profile pendants (pendientes cefalomorfos) could be reworked raptorial bird pendants (also Durand and Petitjean-Roget 1991). In summary, we note elements traditionally attributed to both series on this assemblage from Pearls. However, no systematic comparison of zoomorphic pendants across Antillean sites has been carried out to date, thus limiting the value of such cultural attributions. 


\section{Raw material management}

The limitations imposed by the unsystematic means by which this collection was formed should not be overlooked. First, the low numbers of artefacts in early production stages may partially be a product of this collection strategy. Second, the absence of chronological control prevents us from grasping how identified patterns may have changed over time. Nevertheless, raw material management patterns can be suggested based on suggested raw material sources and on the technical stages identified in the collection (Table 4). We recorded a large number of amethyst artefacts, encompassing most beadmaking stages. Pearls was likely the main provider of amethyst beads to the islands to the north. Similar percentages of quartz and carnelian unfinished ornaments and debitage were found. Even though carnelian artefacts are less numerous $(n=$ 66), more than half of them are in the form of production waste. Therefore, at least part of the manufacture of carnelian beads took place at Pearls. Carnelian pebbles and preforms were brought from Antigua (the geological source) or Montserrat and were locally made into beads using the same procedures used for amethyst and quartz.

Diorite is the most prevalent raw material in the collection, but presents only $19.4 \%$ of unfinished specimens. A large number of similar diorite beads are also reported from Trants, with an even lower percentage of unfinished specimens (Watters and Scaglion 1994, 226). Some diorite beadmaking activities took place at Pearls, as already noted by Cody $(1990,41)$. The lack of rough-outs and debitage suggests that there was a focus on the last stages of the production sequence, such as fine grinding, polishing and drilling. Diorite and other plutonic rocks are not commonly found on Grenada, so they had to be brought in. Diorite could be obtained from Tobago, from where geological sources and bead workshop sites are known (Boomert and Rogers 2007). Whereas the occupation of the Golden Grove site on Tobago starts at a later period (AD 690-900), there is an overlap with the newly calibrated dates for Pearls (Hanna 2019). Regarding the other plutonic rocks, there is evidence for the production of geometric pendants, but no evidence for the production of yellowish plutonic rock beads.

Other lapidary workshop sites contain few turquoise ornaments. Despite their large numbers in the Pearls collection, turquoise is represented by almost exclusively finished beads and pendants $(91.1 \%)$. Most specimens have small sizes $(1.0 \mathrm{~cm}$ of diameter or less) and large portions of brownish matrix. Jadeitite is found in large numbers in the studied collection, even though its presence in other lapidary workshops has been contested. In the studied group, non-modified pebbles and preforms represent nearly $25 \%$. Among pendants, $49.1 \%$ are unfinished. Therefore, similarly to plutonic rocks, there is more evidence of pendant production, despite the predominance of beads in the assemblage.
Nephrite ornaments have been reported from many sites, but in low numbers and with limited production evidence. This pattern is repeated in the studied collection, although there are some unfinished specimens $(n=7 ; 26.9 \%)$. Most unfinished specimens are made from a light coloured and translucent variety of nephrite (e.g. Supplementary data 9, c). Most nephrite pendants have a dark colour and are not markedly translucent; this variety was probably obtained as finished pendants. The metamorphic rocks with tremolite include a large number of unfinished specimens mostly related to pendant production $(n=17 ; 62.9 \%)$. The other two raw material categories, metamorphosed ultramafics and low temperature hydrothermal alteration products, include large percentages of unfinished beads and pendants (54.5\% and 59.3\%, respectively).

\section{Ornament production technologies}

The working of ornaments made of quartz varieties follows a relatively standardized sequence for bead production. It involved flaking for blank acquisition and shaping, followed by pecking, two stages of grinding, polishing and drilling. The creation of long and regular perforations on hard materials demonstrates great skill in ornament making. The general production sequence remains largely the same across different ornament types. The main differences are related to blank production and blank morphology, which are chosen according to the desired end product. Two techniques were identified for blank production through flaking: direct hard hammer percussion and percussion on an anvil. However, the low amount of debitage prevents further insights on their use. We also identified varied surface treatments used on different ornaments and even on different sectors of a same specimen.

Abrasive techniques had not been previously investigated in the Caribbean. Their identification is a direct result of the microwear analysis. Non-quartz raw materials have been used for the production of multiple bead and pendant types. Prior to this study, no information was available on how such ornaments were produced. We identified the use of diverse blank production and shaping techniques, even within a same raw material group. For instance, turquoise and diorite tubular beads were produced from both multi-bead preforms and from flake blanks. Likewise, pendants were produced through the use of both string sawing and rigid lithic saws. Different decorative tools and techniques have also been identified, alongside vast stylistic diversity in carved pendants. Technological variability may have corresponded to differences in production loci within the site, to diachronic variation or to the production of some artefacts in another workshop. Nonetheless, the diversity of raw materials being worked highlights the great technological achievement of the indigenous inhabitants of the Caribbean to a degree that had not been previously attested. 


\section{The use of ornaments}

Most analysed macro- and microcrystalline quartz ornaments did not display use-wear, despite their presence in large numbers. It is therefore possible that certain locally produced ornaments were not for local use, even though the raw materials were brought from other islands or even from South America. In other words, Pearls would have been primarily a production site for amethyst, quartz and carnelian. A specific pattern has also been noted for nephrite ornaments: all but one of the analysed specimens displayed use-wear. Three-dimensional frog-shaped pendants have been reported from funerary contexts in many eastern Caribbean sites (Bonnissent 2008, 103; Durand and Petitjean-Roget 1991), including Pearls (Cody 1990, 44, 50). We can thus suggest that nephrite ornaments were acquired through exchange, used as bodily adornment and ultimately deposited with the dead. Jadeitite, diorite, other plutonic rocks and turquoise assemblages also include large percentages of worn specimens (Table 3). Whether they arrived as raw material, finished or unfinished specimens, some among them were used at the site. In this sense, we do not observe a clear opposition between ornaments locally produced for export and imported raw materials for local use. Lapidary materials were dealt with in different ways depending on their raw material and ornament type. This preliminary use-wear study demonstrates that, rather than being exclusively valuables kept in circulation, certain ornaments were also produced or acquired to be worn in Pearls itself. This is in agreement with the retrieval of ornaments from domestic middens during the excavations of the site (Cody 1990, 42-43).

\section{Conclusion}

The typo-technological and microwear study of the Pearls collection provides new perspectives on the production and use of ornaments in the Caribbean. The collection is comparable with those retrieved from other sites of the Early Ceramic Age period, although notably large and with great variety of ornament materials and types. The presence of large quantities of allochthonous materials from different geological sources reinforces the role of Pearls as an important node in far-reaching networks. Some materials may have come from nearby Windward Islands and South America, while others may have come from the Leeward Islands, the Greater Antilles or even from Central America. We identified a marked focus on the production of beads made of quartz varieties, thus reframing previous ideas regarding sole specialization on amethyst beads at Pearls. The preliminary results of the use-wear study suggest that these exotic materials were made into ornaments to be (at least partially) sent away once again, rather than locally worn.
The identification of jadeitite pendant production at the site is unprecedented in the region. Unmodified pebbles, ornaments in different technical stages and used specimens were part of the collection. This was also observed for diorite, nephrite and turquoise, but to rather different degrees. These materials were likely being circulated across the Caribbean sea in different technical stages. Further insights on their circulation will require analytical studies focused on material characterization and provenance. The results of these studies will be reported in a future publication (Knaf et al. in prep).

The present study further demonstrates the technological variability and expertise present in the Early Ceramic Age. A deliberate choice was made in this period for investing time and skill in ornament making, as opposed to other lithic industries considered to be opportunistic, expedient and lacking standardization (Crock and Bartone 1998). The high skill in lapidary working is demonstrated by the use of a large variety of raw materials and the development of a range of techniques and toolkits suited to work them. The typo-technological study of the entire collection combined with the microscopic analysis of a selected sample provided insights into the production sequences applied to all raw materials, even to those that are neither numerous nor present in multiple technical stages (for instance, nephrite and turquoise). Likewise, it allowed us to identify production techniques that remained invisible in previous studies, such as (1) sawing with rigid saws and string sawing as blank acquisition strategies and (2) different types of grinding and polishing. The reduction of hard materials through abrasive techniques is notably time-consuming, in particular, through grinding and sawing. In this sense, their specialized use is evidence of the knowledge, skill and time invested in ornament making in the past.

The role of the different islands in Early Ceramic Age networks needs to be further studied, in particular, by reanalysing previously excavated (legacy) collections and by applying an interdisciplinary approach. In-depth technological studies of other sites can highlight craft differences between islands. Only then will we be able to assign specific technical products to a given workshop, rather than just raw material groups and ornament types.

Acknowledgements The authors would like to thank the Willcox family for allowing access to the collection. Angus Martin is also thanked for his help during this research. Finally, we would like to acknowledge the support of the Grenada Ministry of Culture.

Funding information This research has received funding from the NWO (Netherlands Organization for Scientific Research) Spinoza Prize awarded to Prof. Dr. Corinne L. Hofman in 2014. This research is part of the project NEXUS1492, which has received funding from the European Research Council under the European Union's Seventh Framework Programme (FP7/2007-2013)/ERC Grant agreement $n^{\circ}$ 319209. 


\section{Compliance with ethical standards}

Conflict of interest The authors declare that they have no conflict of interest.

Open Access This article is licensed under a Creative Commons Attribution 4.0 International License, which permits use, sharing, adaptation, distribution and reproduction in any medium or format, as long as you give appropriate credit to the original author(s) and the source, provide a link to the Creative Commons licence, and indicate if changes were made. The images or other third party material in this article are included in the article's Creative Commons licence, unless indicated otherwise in a credit line to the material. If material is not included in the article's Creative Commons licence and your intended use is not permitted by statutory regulation or exceeds the permitted use, you will need to obtain permission directly from the copyright holder. To view a copy of this licence, visit http://creativecommons.org/licenses/by/4.0/.

\section{References}

Acevedo Gómez N, Scharff MW, García-Casco A, Sáenz-Samper J (2018) Placas aladas de las sociedades Nahuange y Tairona (100 1600 dc), Sierra Nevada de Santa Marta, Colombia: Materia prima y áreas de procedencia. Lat Am Antiq 29(4):774-792. https://doi.org/ 10.1017/laq.2018.51

Alminas HV, Foord EE, Tucker RE (1994) Geochemistry, mineralogy, and geochronology of the U.S. Virgin Islands. Washington: United States Government Printing Office

Arculus RJ (1976) Geology and geochemistry of the alkali basaltandesite association of Grenada, Lesser Antilles island arc. Geol Soc Am Bull 87(4):612-624. https://doi.org/10.1130/00167606(1976)87<612:GAGOTA >2.0.CO;2

Arculus RJ, Wills KJ (1980) The petrology of plutonic blocks and inclusions from the Lesser Antilles island arc. J Petrol 21(4):743-799. https://doi.org/10.1093/petrology/21.4.743

Beck RJ, Mason M (2002) Mana Pounamu. New Zealand jade. Auckland, Reed

Bérard B (2013) The Saladoid. In: Keegan WF, Hofman CL, Rodríguez Ramos R (eds) The Oxford Handbook of Caribbean Archaeology. Oxford University Press, Oxford, pp 184-197

Bonnissent D (2008) Archéologie précolombienne de l'île de SaintMartin, Petites Antilles (3300 BC-1600 AD). Dissertation, Université de Provence Aix-Marseille I

Boomert A (1987) Gifts of the Amazons: "greenstone" pendants and beads as items of ceremonial exchange in Amazonia and the Caribbean. Antropológica 67:33-54

Boomert A (2001) Saladoid sociopolitical organization. In: Proceedings of the XVIII International Congress for Caribbean Archaeology, Grenada, July 11-17, 1999. Guadeloupe, L'Association Internationale d'Archéologie de la Caraïbe, pp 55-77

Boomert A (2007) Exotics from Pearls, Grenada. A preliminary assessment. In: Proceedings of the XXII Conference of the International Association for Caribbean Archaeology (IACA), Kingston, Jamaica, July 23-29, 2007. Kingston, International Association for Caribbean Archaeology, pp 1-25

Boomert A, Rogers CT (2007) Troumassoid stone artifacts in Tobago: rock types and source areas. In: Reid BA, Petitjean-Roget H, Curet LA (eds) Proceedings of the Twenty-First Congress of the International Association for Caribbean Archaeology, Volume 1, Trinidad and Tobago, vol 2005. The University of the West Indies, St. Augustine, pp 282-294
Breukel TW (2019) Tracing interactions in the indigenous Caribbean through a biographical approach: microwear and material culture across the historical divide (AD 1200-1600). Dissertation, Leiden University

Breukel TW, Falci CG (2017) Experimental reproduction of wear traces on shell, coral, and lithic materials from the pre-colonial Caribbean. In: Velasquez CB, Haviser JB (eds) Proceedings of the 26th Congress of the IACA (International Association for Caribbean Archaeology). Sint Maarten, SIMARC

Bullen RP (1964) The archaeology of Grenada, West Indies. University of Florida, Gainesville

Cahen D, Karlin C, Keeley LH, Van Noten F (1980) Méthodes d'analyse technique, spatiale et fonctionnelle d'ensembles lithiques. Helinium Wetteren 20(3):209-259

Chanlatte Baik LA (1983) Catálogo Arqueología de Vieques. Exposición del 13 de marzo al 22 de abril de 1983. Santo Domingo: Editora Corripio

Chanlatte Baik LA, Narganes Storde YM (1989) La nueva arqueologia de Puerto Rico (su proyección en las Antillas). Boletin del Museo del Hombre Dominicano 22:9-49

Cody AK (1990) Prehistoric patterns of exchange in the Lesser Antilles: materials, models, and preliminary observations. Master thesis, San Diego State University

Cody AK (1993) Distribution of exotic stone artifacts through the Lesser Antilles: their implications for prehistoric interaction and exchange. In: Cummins A, King P (eds) Proceedings of the Fourteenth International Congress for Caribbean Archaeology, Dover Convention Centre, Barbados, 22-28 July 1991. Bridgetown, Barbados Museum and Historical Society, pp 204-226

Costa ML, Silva ACRL, Angélica RS, Pöllmann H, Schuckmann W (2002) Muyrakytã ou Muiraquitã: Um talismã arqueológico em jade procedente da Amazônia: aspectos físicos, mineralogia, composição química e sua importância etnogeológica. Acta Amazônica 32(3): 431-448. https://doi.org/10.1590/1809-43922002323448

Costa ML, Fernández OC, Toledo MCM, Passos CM, Pereira PF (2004) A turquesa de Itacupim, Pará. Rem: Revista da Escola de Minas 57 (4):261-266. https://doi.org/10.1590/S037044672004000400008

Crock JG, Bartone RN (1998) Archaeology of Trants, Montserrat. Part 4. Flaked stone and stone bead industries. Annals of the Carnegie Museum 67(3):197-224

Curet LA (2003) Issues on the diversity and emergence of middle-range societies of the ancient Caribbean: a critique. J Archaeol Res 11(1): 1-42. https://doi.org/10.1023/A:1021277308225

Curet LA, Hauser MW (eds) (2011) Islands at the crossroads: migration, seafaring, and interaction in the Caribbean. University of Alabama Press, Tuscaloosa

d'Errico F, Roux V, Dumond Y (2000) Identification des techniques de finition des perles en calcédoine par l'analyse microscopique et rugosimétrique. In: Roux V (ed) Cornaline de l'Inde. Des pratiques techniques de Cambay aux techno-systèmes de l'Indus. Maison des sciences de l'homme, Paris, pp 97-169

De Mille CN, Varney TL, Turney MHJ (2008) Saladoid lapidary technology: new methods for investigating stone bead drilling techniques. In: Hofman CL, Hoogland MLP, Van Gijn AL (eds) Crossing the borders: new methods and techniques in the study of archaeological materials from the Caribbean. University of Alabama Press, Tuscaloosa, pp 78-89

Durand JF, Petitjean-Roget H (1991) A propos d'un collier funéraire à Morel, Guadeloupe: Les Huecoïdes sont-ils un mythe? In: Sickler Robinson L (ed) Proceedings of the Twelfth Congress of the International Association for Caribbean Archaeology, Cayenne, Juillet/Aôut 1987. Association Internationale d'Archéologie de la Caraïbe, Martinique, pp 53-70

Epstein DS (1988) Amethyst mining in Brazil. Gems and Gemology 24(4):214-228 
Falci CG (2015) Stringing beads together: a microwear study of bodily ornaments in late pre-colonial north-central Venezuela and northwestern Dominican Republic. Leiden University, Research Master thesis

Falci CG, Rodet MJ (2016) Adornos corporais em Carajás: a produção de contas líticas em uma perspectiva regional. Boletim do Museu Paraense Emílio Goeldi. Ciências Humanas 11(2):481-503. https://doi.org/10.1590/1981.81222016000200008

Falci CG, Van Gijn AL, Antczak MM, Antczak AT, Hofman CL (2017) Challenges for microwear analysis of figurative shell ornaments from pre-colonial Venezuela. J Archaeol Sci Rep 11:115-130. https://doi.org/10.1016/j.jasrep.2016.11.029

Fitzpatrick SM (2012) On the shoals of giants: natural catastrophes and the overall destruction of the Caribbean's archaeological record. J Coast Conserv 16(2):173-186. https://doi.org/10.1007/s11852-0100109-0

Foshag WF, Leslie R (1955) Jadeite from Manzanal, Guatemala. Am Antiq 21:81-83. https://doi.org/10.2307/276111

García-Casco A, Rodríguez Vega A, Cárdenas Párraga J, Iturralde-Vinent MA, Lázaro C, Blanco-Quintero I, Rojas Agramonte Y, Kröner A, Núñez Cambra K, Millán G, Torres-Roldán RL, Carrasquilla S (2009) A new jadeitite jade locality (Sierra del Convento, Cuba): first report and some petrological and archeological implications. Contrib Mineral Petrol 158:1-16. https://doi.org/10.1007/s00410008-0367-0

García-Casco A, Knippenberg S, Rodríguez Ramos R, Harlow GE, Hofman CL, Pomo JC, Blanco-Quintero IF (2013) Pre-Columbian jadeitite artifacts from the Golden Rock Site, St. Eustatius, Lesser Antilles, with special reference to jadeitite artifacts from Elliot's, Antigua: implications for potential source regions and long distance exchange networks in the Greater Caribbean. J Archaeol Sci 40: 3153-3169. https://doi.org/10.1016/j.jas.2013.03.025

Groman-Yaroslavski I, Bar-Yosef Mayer DE (2015) Lapidary technology revealed by functional analysis of carnelian beads from the early Neolithic site of Nahal Hemar Cave, southern Levant. J Archaeol Sci 58:77-88. https://doi.org/10.1016/j.jas.2015.03.030

Gurova M, Bonsall C, Bradley B, Anastassova E (2013) Approaching prehistoric skills: experimental drilling in the context of bead manufacturing. Bulgarian e-journal Archaeol 3(2):201-221

Gwinnett AJ, Gorelick L (1979) Ancient lapidary. A study using scanning electron microscopy and functional analysis. Expedition 22(1):1732

Hanna JA (2019) Camáhogne's chronology: the radiocarbon settlement sequence on Grenada, West Indies. J Anthropol Archaeol 55: 101075. https://doi.org/10.1016/j.jaa.2019.101075

Hanna JA, Jessamy M (2017) The St. John's river site: public archaeology of the Troumassoid period in Grenada, West Indies. In: Velasquez CB, Haviser JB (eds) Proceedings of the 26th Congress of the International Association for Caribbean Archaeology. Sint Maarten, SIMARC

Hardy MD (2008) Saladoid economy and complexity on the Arawakan frontier. Dissertation, Florida State University

Harlow GE, Murphy AR, Hozjan DJ, De Mille CN, Levinson AA (2006) Pre-Columbian jadeite axes from Antigua, West Indies: description and possible sources. Can Mineral 44:305-321. https://doi.org/10. 2113/gscanmin.44.2.305

Harlow GE, Sisson VB, Sorensen SS (2011) Jadeitite from Guatemala: new observations and distinctions among multiple occurrences. Geol Acta 9(3-4):363-387. https://doi.org/10.1344/105.000001694

Haviser JB (1999) Hope estate: lithics. In: Hofman CL, Hoogland MLP (eds) Archaeological Investigations on St. Martin (Lesser Antilles). The sites of Norman Estate, Anse des Peres, and Hope Estate. With a contribution to the 'La Hueca Problem'. Leiden University Press, Leiden, pp 189-202
Hofman CL, Hoogland MLP (2016) Connecting stakeholders: collaborative preventive archaeology projects at sites affected by natural and/ or human impacts. Caribbean Connections 5(1):1-31

Hofman CL, Bright AJ, Boomert A, Knippenberg S (2007) Island rhythms: the web of social relationships and interaction networks in the lesser Antillean archipelago between 400 BC and AD 1492. Lat Am Antiq 18(3):243-268. https://doi.org/10.2307/25478180

Hofman CL, Mol AAA, Rodríguez Ramos R, Knippenberg S (2014a) Networks set in stone: Archaic-Ceramic interaction in the early precolonial northeastern Caribbean. In: Bérard B, Losier C (eds) Archéologie Caraïbe. Sidestone Press, Leiden, pp 119-132

Hofman CL, Mol AAA, Hoogland MLP, Valcárcel Rojas R (2014b) Stage of encounters: migration, mobility and interaction in the precolonial and early colonial Caribbean. World Archaeol 46(4):590 609. https://doi.org/10.1080/00438243.2014.925820

Hofman CL, Borck L, Slayton E, Hoogland MLP (2019) Archaic Age voyaging, networks, and resource mobility around the Caribbean Sea. In: Hofman CL, Antczak AT (eds) Early Settlers of the Insular Caribbean. Dearchaizing the Archaic. Sidestone Press, Leiden, pp 245-261

Inizan ML, Reduron-Ballinger M, Roche H, Tixier J (1999) Technology and terminology of knapped stone. Cercle de Recherches et d'Etudes Préhistoriques, Nanterre

Keegan WF, Cody AK (1990) Progress Report on the Archaeological Excavations at the Site of Pearls, Grenada, August 1989. Florida Museum of Natural History, Gainesville

Keegan WF, Hofman CL (2017) The Caribbean before Columbus. Oxford University Press, Oxford

Kenoyer JM, Vidale M (1992) A new look at stone drills of the Indus Valley tradition. In: Vandiver P, Druzick JR, Wheeler GS, Freestone I (eds) Materials issues in art and archaeology III. Pittsburgh, Materials Research Society, pp 495-518

Kenoyer JM, Vidale M, Bhan KK (1991) Contemporary stone beadmaking in Khambhat, India: patterns of craft specialization and organization of production as reflected in the archaeological record. World Archaeol 23(1):44-63. https://doi.org/10.1080/ 00438243.1991 .9980158

Knippenberg S (2007) Stone artefact production and exchange among the Northern Lesser Antilles. Leiden University Press, Leiden

Kovacevich B (2011) The organization of jade production at Cancuen, Guatemala. In: Hruby ZX, Braswell GE, Mazariegos OC (eds) The Technology of Maya civilization: political economy and beyond in lithic studies. Equinox, London, pp 149-161

Laffoon JE, Rodríguez Ramos R, Chanlatte Baik LA, Narganes Storde YM, Rodríguez López M, Davies GR, Hofman CL (2014) Longdistance exchange in the precolonial circum-Caribbean: a multiisotope study of animal tooth pendants from Puerto Rico. J Anthropol Archaeol 35:220-235. https://doi.org/10.1016/j.jaa. 2014.06.004

Melgar Tísoc EM, Solís Ciriaco RB, Filloy Nadal L (2013) Análisis tecnológico de las piezas de jadeíta y pedernal del cinturón de poder y de la banda frontal de K'inich Jannab'Pakal de Palenque. In: Velázquez Castro A, Lowe LS (eds) Técnicas Analíticas Aplicadas a la Caracterización y Producción de Materiales Arqueológicos en el Área Maya. Universidad Autónoma de México, México, pp 135162

Mol AAA (2014) The connected Caribbean. In: A socio-material network approach to patterns of homogeneity and diversity in the precolonial period. Sidestone Press, Leiden

Murphy AR, Hozjan DJ, De Mille CN, Levinson AA (2000) PreColumbian gems and ornamental materials from Antigua, West Indies. Gems and Gemology 36(3):234-245

Narganes Storde YM (1995) La lapidaria de La Hueca, Vieques, Puerto Rico. In: Alegría RE, Rodríguez M (eds) Proceedings of the XV International Congress for Caribbean Archaeology, San Juan, 
Puerto Rico, July 25th-30th 1993. San Juan, Centro de Estudios Avanzados de Puerto Rico y el Caribe, pp 141-151

Narganes Storde YM (1999) La lapidaria de Sorcé, Vieques y Tecla, Guayanilla, Puerto Rico. In: Richard G (ed) Proceedings of the XVI International Congress for Caribbean Archaeology Part II. Basse-Terre, July 24-28th, 1995. Conseil Régional de la Guadeloupe et Auditorium de la Ville de Basse-Terre, Basse-Terre, pp 17-26

Oldershaw C (2009) Gems of the world. Firefly, New York

Oliver JR (1999) The La Hueca complex in the West Indies: old problems, new perspectives, possible solutions. In: Hofman CL, Hoogland MLP (eds) Archaeological investigations on St. Martin (Lesser Antilles). The sites of Norman Estate, Anse des Pères, and Hope Estate. With a contribution to the 'La Hueca problem'. Leiden University Press, Leiden, pp 253-297

Perlès C (2007) Échanges et technologie: L'exemple du Néolithique. In: Évin $\mathrm{J}$ (ed) Un siècle de construction du discours scientifique en Préhistoire. Volume III. Société préhistorique française, Paris, pp 53-62

Petitjean Roget H (2015) Archéologie des Petites Antilles. Chronologies, art ceramique et art rupestre. Association Internationale d'Archéologie de la Caraibe, Basse Terre

Pétrequin P, Bontemps C, Buthod-Ruffier D, Le Maux N (2012) Approche expérimentale de la production des haches alpines. In: Pétrequin P, Cassen S, Errera M, Klassen L, Sheridan A, Pétrequin AM (eds) Jade. Grandes haches alpines du Néolithique européen. Ve et IVe millénaires av. J.-C. Tome 1. Presses Universitaires de Franche-Comté et Centre de Recherche Archéologique de la Vallée de l'Ain, Besançon, pp 258-291

Procopiou H, Morero E, Vargiolu R, Suarez-Sanabria M, Zahouani H (2013) Tactile and visual perception during polishing: an ethnoarchaeological study in India (Mahabalipuram, Tamil Nadu). Wear 301(1-2):144-149. https://doi.org/10.1016/j.wear.2012.11.058

Queffelec A, Fouéré P, Paris C, Stouvenot C, Bellot-Gurlet L (2018) Local production and long-distance procurement of beads and pendants with high mineralogical diversity in an early Saladoid settlement of Guadeloupe (French West Indies). J Archaeol Sci Rep 21: 275-288. https://doi.org/10.1016/j.jasrep.2018.07.011

Rapp GR (2009) Archaeo-mineralogy. Springer, Berlin

Rodríguez López MA (1991) Arqueología de Punta Candelero, Puerto Rico. In: Ayubi EN, Haviser JB (eds) Proceedings of the Thirteenth International Congress for Caribbean Archaeology Part 2, July 1989, Curaçao, Netherlands Antilles. Willemstad, pp 605-627

Rodríguez López MA (1993) Early trade networks in the Caribbean. In: Cummins A, King P (eds) Proceedings of the Fourteenth International Congress for Caribbean Archaeology, Dover Convention Centre, Barbados, 22-28 July 1991. Bridgetown: Barbados Museum and Historical Society, pp 306-314

Rodríguez Ramos R (2010) Rethinking Puerto Rican precolonial history. University Alabama Press, Tuscaloosa

Rodríguez Ramos R (2011) The circulation of jadeitite across the Carribeanscape. In: Hofman CL, Van Duijvenbode A (eds) Communities in contact. Sidestone Press, Leiden, pp 116-136

Rodríguez Ramos R, Torres J, Oliver JR (2010) Rethinking time in Caribbean archaeology. The Puerto Rico case study. In: Fitzpatrick SM, Ross AH (eds) Island shores, distant pasts: archaeological and biological approaches to the pre-Columbian settlement of the Caribbean. University Press of Florida, Gainesville, pp 21-53

Roe PG (1989) A grammatical analysis of Cedrosan Saladoid vessel form categories and surface decorations: aesthetic and technical styles in early Antillean ceramics. In: Siegel PE (ed) Early ceramic population lifeways and adaptive strategies in the Caribbean. Archaeopress, Oxford, pp 267-382

Rouse IB (1992) The Tainos: rise and decline of the people who greeted Columbus. Yale University Press, New Haven

Rouse IB, Alegría RE (1990) Excavations at Maria de la Cruz Cave and Hacienda Grande Village Site, Loiza, Puerto Rico. Yale University Press, New Haven

Roux V (ed) (2000) Cornaline de l'Inde: Des pratiques techniques de Cambay aux techno-systèmes de l'Indus. Paris: Editions de la Maison des Sciences de l'Homme. https://doi.org/10.4000/books.editionsmsh.8706

Sax M, Ji K (2013) The technology of jades excavated at the Western Zhou, Jin Marquis cemetery, Tianma-Qucun, Beizhao, Shanxi province: recognition of tools and techniques. J Archaeol Sci 40(2): 1067-1079. https://doi.org/10.1016/j.jas.2012.08.041

Schertl H-P, Maresch WV, Stanek KP, Hertwig A, Krebs M, Baese R, Sergeev SS (2012) New occurrences of jadeitite, jadeite quartzite and jadeite lawsonite quartzite in the Dominican Republic, Hispaniola: petrological and geochronological overview. Eur J Mineral 24:199-216. https://doi.org/10.1127/0935-1221/2012/0024-2201

Scott RB, Neyt B, Hofman CL, Degryse P (2018) Determining the provenance of Cayo pottery from Grenada, Lesser Antilles, using portable X-ray fluorescence spectrometry. Archaeometry 60(5):966-985. https://doi.org/10.1111/arcm.12359

Sellet F (1993) Chaîne opératoire; the concept and its applications. Lithic Technol 18(1-2):106-112. https://doi.org/10.1080/01977261.1993. 11720900

Siegel PE (2010) Continuity and change in the evolution of religion and political organization on pre-Columbian Puerto Rico. J Anthropol Archaeol 29(3):302-326. https://doi.org/10.1016/j.jaa.2010.04.002

Soressi M, Geneste JM (2011) The history and efficacy of the chaîne opératoire approach to lithic analysis: studying techniques to reveal past societies in an evolutionary perspective. PaleoAnthropology: 334-350. https://doi.org/10.4207/PA.2011.ART63

Van Gijn AL (2012) New perspectives for microwear analysis. In: Bakels CC, Kamermans H (eds) The End of our Fifth Decade. Faculty of Archaeology, Leiden University (Analecta praehistorica leidensia 43/44), Leiden, pp 275-282

Verchoof WB, Van der Vaart S (2010) Amber clubs and axes; how are they made? Production experiments with amber ornaments performed at Lands of Legends Lejre during the summer of 2010. Report on file at the Laboratory for Artefact Studies, Leiden University

Vescelius GS, Robinson LS (1979) Exotic items in archaeological collections from St. Croix: prehistoric imports and their implications. Paper presented to the Eighth International Congress for the Study of the Pre-Columbian Cultures of the Lesser Antilles, St. Kitts

Watters DR (1997) Maritime trade in the prehistoric eastern Caribbean. In: Wilson SM (ed) The indigenous people of the Caribbean. University Press of Florida, Gainesville, pp 88-99

Watters DR, Scaglion R (1994) Beads and pendants from Trants, Montserrat: implications for the prehistoric lapidary industry of the Caribbean. Annals of the Carnegie Museum 63(3):215-237

Wright KI, Critchley P, Garrard A, Bains R, Baird D, Groom S (2008) Stone bead technologies and early craft specialization: insights from two Neolithic sites in eastern Jordan. Levant 40(2):131-165. https:// doi.org/10.1179/175638008X348016

Publisher's note Springer Nature remains neutral with regard to jurisdictional claims in published maps and institutional affiliations. 